\title{
FENOMENA PENGGUNAAN MAGI PADA KALANGAN SINDEN DI KABUPATEN SUBANG - JAWA BARAT (STUDI TENTANG SISTEM RELIGI)
}

\author{
THE PHENOMENA OF THE USE OF MAGIC IN SINDEN \\ OF SUBANG REGENCY-WEST JAVA \\ (THE STUDY OF BELIEFS SYSTEM)
}

\author{
Rosyadi \\ Balai Pelestarian Nilai Budaya (BPNB) Bandung \\ Jalan Cinambo 136 Ujungberung - Bandung \\ e-mail: ochadroki@yahoo.com
}

\begin{abstract}
Abstrak
Di lingkungan masyarakat Sunda, khususnya pada kalangan seniman Sunda, daerah Subang dikenal sebagai "lumbung" sinden yang telah mengorbitkan dan mengantarkan beberapa nama sinden ke puncak popularitasnya. Kondisi ini tidak luput dari lingkungan sosial budaya masyarakat Subang itu sendiri yang gemar berkesenian, baik sebagai seniman praktisi, pemerhati, maupun penikmat karya seni tradisional. Di samping itu, masyarakat Subang yang dalam kehidupan religinya masih kuat memegang adat istiadat, juga turut memengaruhi perkembangan seni sinden. Kepercayaan masyarakat setempat terhadap dunia gaib dan kekuatan-kekuatan gaib, turut pula mewarnai perkembangan dunia pesinden di daerah ini. Tidak sedikit para sinden di daerah Subang yang memanfaatkan tenaga-tenaga magis yang diperoleh melalui ritual-ritual tertentu ataupun melalui jasa paranormal, seperti dukun dan kuncen. Tulisan ini berupaya menggali penggunaan magi pada kalangan sinden yang telah lama menggejala di daerah Subang. Penelitian ini merupakan penelitian kualitatif serta menggunakan metode deskriptif dengan teknik memaparkan berbagai fenomena yang didapati di lapangan terkait dengan penggunaan magi oleh sinden, selanjutnya dianalisis menggunakan teori-teori kebudayaan.
\end{abstract}

Kata kunci: magi, religi, sinden.

\begin{abstract}
In Sundanese community, especially in sundanese artist, Subang area well known as 'the centre' of sinden (women singer) that has bring a popularity for several singer. This condition are related to the social and cultural of Subang society that love arts, even though as practitioner, observer, or devotee/spectator of traditional arts. Meanwhile, the life of their beliefs still hold the customs, and it's also influenced the developing of sinden arts. Believe in superstition also enriching the sinden worlds in this area. A lot of sinden who utilize magical power through rituals or paranormal services. This paper are try to dig deeper about the use of magical power in sinden of Subang area. This research is qualitative research, and use descriptive method, with roll out several of phenomena in the field that related to the use of magical power by sinden. The next step is analysis by using the theory of culture.
\end{abstract}

Keywords: Magic, Religion, sinden. 


\section{A. PENDAHULUAN}

Seni merupakan aktivitas daya kreativitas manusia dalam mengolah rasa dan semua aktivitas emosional yang menghasilkan karya yang indah. Dalam seni terkandung rasa keindahan yang terkait langsung dengan kebutuhan batiniah. Unsur seni inilah yang jelas membedakan manusia dengan makhlukmakhluk lainnya.

Sekalipun kesenian dicirikan dari keindahannya, akan tetapi kesenian tidak hanya dapat dikaji dari sudut penataan artistiknya saja, akan tetapi kesenian juga dapat dilihat dan dikaji dari sudut latar belakang kebudayaannya. Dalam pandangan ini kajian seni justru akan memberikan penjelasan lebih luas yang akan mampu mengungkap makna simbolik dari kesenian tersebut.

Di dalam konteks kebudayaan, kesenian merupakan bagian penting dan tak terpisahkan dari kebudayaan manusia. Bahkan, dalam pandangan sempit, tidak jarang orang mengartikan dan mengidentikkan kebudayaan sebagai kesenian (Nalan, 2008). Padahal, dalam pengertian yang lebih luas, kesenian merupakan salah satu unsur dari kebudayaan yang sifatnya universal; artinya, bahwa unsur kesenian ini terdapat pada hampir semua kebudayaan di mana pun. Betapapun sederhananya suatu kebudayaan, pastilah di dalamnya terdapat unsur kesenian.

Fenomena faktual yang kita dapati sekarang ini mengenai keberadaan kesenian tradisional menunjukkan adanya beberapa jenis kesenian tradisional yang sudah semakin melemah keberadaannya.

Banyak di antara kesenian tradisional yang pada masanya dulu sempat "berjaya", kini keberadaannya terancam punah. Ia mulai terpinggirkan dan tersisihkan oleh kesenian-kesenian baru yang belum tentu sesuai dengan budaya bangsa kita. Kondisi ini banyak dialami oleh kesenian-kesenian tradisional, sehingga tidak jarang keseniankesenian tradisional, khususnya yang ada di daerah-daerah, kini tengah mengalami krisis, bahkan ada beberapa di antaranya yang sudah mulai punah.

Kesenian-kesenian tradisional Sunda di Jawa Barat pun mengalami hal yang sama. Beberapa seni tradisi di Jawa Barat tengah berjalan menuju kepunahan. Hal ini dibuktikan dengan punahnya 55 jenis seni tradisi di Jawa Barat. Sedangkan 77 jenis kesenian lainnya dalam kondisi tidak dapat berkembang. Seni tradisi itu sudah masuk daftar museum, karena sudah sulit diidentifikasi dan dideskripsikan, serta pelakunya sudah tiada. Sementara itu 78 seni tradisi lainnya dapat berkembang. Demikian hasil penelitian Atiek Soepandi dan beberapa stakeholder mengenai keberadaan seni tradisi di Jawa Barat (1986/1987:28)

Sementara itu, Direktur Jenderal Nilai Budaya, Seni dan Film, Kementerian Kebudayaan dan Pariwisata RI, Ukus Kuswara pada Dialog Budaya di Kabupaten Kuningan September 2011, mengemukakan bahwa pada saat ini ada 150 kesenian, yang sebagian besar terancam punah. Sangat disayangkan kalau kondisi seperti ini dibiarkan begitu saja.

Dalam tinjauan sejarah kebudayaan, kesenian memiliki kaitan yang sangat erat dengan aspek-aspek spiritual dan religi masyarakat. Beberapa jenis kesenian tradisional lahir sebagai jawaban atas tuntutan dan kebutuhan-kebutuhan spiritual dan batiniah masyarakat. Sebagai contoh, kesenian angklung buhun pada masyarakat Baduy yang berkaitan dengan kepercayaan masyarakat terhadap Dewi Sri atau Sanghyang Pohaci; Cingcowong di Kuningan, dan beberapa jenis kesenian lainnya yang lahir dari tuntutan spiritual masyarakatnya yang dilandasi oleh sistem kepercayaan atau religi yang diyakininya.

Masyarakat Subang secara formal menganut agama Islam, namun dalam kehidupan kesehariannya terutama yang terkait dengan kehidupan spiritual, masih sangat kental diwarnai oleh tradisi-tradisi yang di luar konteks keislaman. Geertz (1989) dan Beatty (2001)seperti dikutip oleh Nanu (2004:93) menyebut hal 
demikian ini dengan istilah Islam Abangan atau awam. Kepercayaan pada makhluk halus dan kekuatan magis selalu ditemukan dalam kehidupan keseharian masyarakat di daerah Subang, tak terkecuali di kalangan para seniman tradisi, seperti sinden, dalang, bajidor ${ }^{l}$ maupun seniman lainnya. Kepercayaan terhadap makhluk gaib dan tenaga magis ini merupakan unsur yang melekat dalam sistem religi masyarakat

Tulisan ini berusaha menggali kaitan antara aspek-aspek spiritual dengan kehidupan berkesenian, khususnya pada kalangan sinden di Kabupaten Subang Provinsi Jawa Barat.

\section{B. METO DE PENELITIAN}

Secara umum ada dua jenis metode penelitian yang biasa digunakan dalam penelitian ilmu-ilmu sosial, yaitu metode kualitatif dan metode kuantitatif. Kedua metode ini selain berbeda dalam jenis datanya, juga berbeda dalam teknik analisisnya. Penelitian kualitatif mengandalkan data kualitatif yang diperoleh melalui teknik wawancara dan observasi, sedangkan penelitian kuantitatif menggunakan data kuantitatif yang diperoleh melalui penyebaran angket dan pengukuran-pengukuran yang menghasilkan angka-angka.

Dalam perkembangannya kemudian, kedua metode ini, khususnya metode kualitatif banyak melahirkan metodemetode baru yang bermuara pada metode kualitatif. Satu di antaranya adalah metode naturalistik kualitatif. Nasution (1988:5) menjelaskan bahwa metode naturalistik kualitatif pada hakikatnya mengamati orang dalam lingkungan hidupnya, berinteraksi dengan mereka, berusaha memahami bahasa dan tafsiran mereka tentang dunia dan sekitarnya.

${ }^{1}$ Bajidor adalah istilah atau sebutan bagi lakilaki penggemar kesenian kliningan yang senantiasa hadir dalam setiap pertunjukan kliningan dan ia ikut menari bersama ronggeng dari group kesenian tersebut.
Data yang diperoleh adalah data kualitatif yang dijaring melalui teknikteknik wawancara dan observasi, dan didukung dengan studi pustaka. Informan ditentukan secara purposif, yaitu tipe sampling yang didasarkan atas pertimbangan atau penilaian peneliti, dengan asumsi bahwa informan yang dipilih representatif untuk populasi. Walaupun demikian, penilaian dan pertimbangan peneliti tidak lepas dari saran, pengetahuan, dan informasi yang diberikan tokoh-tokoh masyarakat, baik tokoh formal maupun tokoh informal. Mengingat hal itu, informan ditentukan secara berantai dari informan yang ditunjuk oleh tokoh masyarakat ke informan lain yang ditunjuk oleh informan pertama yang telah diwawancarai. Teknik ini disebut sebagai teknik snowball sampling (Bagdan dan Wilken,1986: 66)

Sebelum masuk pada pembahasan mengenai fenomena penggunaan magi pada kalangan sinden, terdapat dua konsep dasar yang perlu diuraikan terlebih dahulu, yaitu konsep magi dan religi. Ada perbedaan yang mendasar antara konsep magi atau ilmu gaib dan religi atau kepercayaan.

\section{Magi}

Magi menurut P.H. Embuiru ${ }^{2}$ berasal dari perkataan Yunani mageia, artinya perbuatan ajaib yang dilakukan golongan imam dari para ahli magi itu. Dalam bahasa Indonesia ada banyak kata untuk magi: ilmu sihir, ilmu gaib, jampi dan sebagainya. Menurutnya, ada dua faktor yang menjadi latar belakang timbulnya magi. Pertama, pandangan tentang dunia dan pandangan tentang hidup menurut orang-orang primitif, yang dalam ilmu agama disebut dinamisme. Artinya siapa yang hidup dan berbuat berdasarkan pandangan tentang hidup yang dinamis itu, berpangkal pada suatu

${ }^{2}$ P.H. Embiru 1979. Magi, dalam http://www.indocell.net/yesaya/pustaka2/id492 .htm

Sumber : "Marga Bahagia" oleh H. Embuiru; Penerbit Nusa Indah 1979, Ende - Flores 
keyakinan bahwa orang-orang tertentu, benda-benda tertentu dan sebagainya mengandung dynamic (daya, kekuatan) yang istimewa. Faktor kedua yang memegang peranan penting dalam magi ialah kepercayaan bahwa orang-orang tertentu dapat menggunakan daya-daya magis untuk tujuan tertentu dengan mantera, suara atau perbuatan.

J.G. Frazer, sebagaimana dikutip oleh Koentjaraningrat (1987:54), menjelaskan bahwa magi (ilmu gaib) adalah segala sistem tingkah laku dan sikap manusia untuk mencapai suatu maksud dengan menguasai dan mempergunakan kekuatankekuatan dan kaidah-kaidah gaib yang ada di dalam alam. Sebaliknya, religi adalah segala sistem tingkah laku manusia untuk mencapai suatu maksud dengan cara menyandarkan diri pada kemauan dan kekuasaan makhluk-makhluk halus seperti roh-roh, dewa-dewa dan sebagainya, yang menempati alam. Dalam penjelasannya mengenai asal usul magi, ia mengemukakan bahwa manusia memecahkan soal-soal hidupnya dengan akal dan sistem pengetahuannya. Akan tetapi akal dan sistem pengetahuan itu ada batasnya. Soalsoal yang tidak dapat dipecahkan dengan akal dipecahkannya dengan magic (ilmu gaib). Namun dalam perkembangan selanjutnya kekuatan magic tersebut tidak selamanya berhasil. Maka manusia mulai sadar bahwa di alam ini ada yang menempatinya yaitu makhluk-makhluk halus. Mulailah manusia mencari hubungannya dengan makhluk-makhluk halus tersebut. Dengan itu timbullah religi. Religi adalah segala sistem tingkah laku manusia untuk memeroleh sesuatu dengan cara memasrahkan diri kepada penciptanya

Dalam kepustakaan ilmu antropologi, kepercayaan dan tindakan-tindakan yang menggunakan atau memanfaatkan kekuatan gaib ini disebut magi. Sebagaimana dijelaskan oleh Koentjaraningrat (1990:288), bahwa magi atau ilmu gaib, adalah teknik-teknik atau kompleks cara yang dipergunakan oleh manusia untuk memengaruhi alam sekitarnya sedemikian rupa hingga sekitarnya itu menuruti kehendaknya dan tujuannya. Adapun dasardasar dari magi atau ilmu gaib adalah: (1) kepercayaan kepada kekuatan sakti; (2) hubungan sebab-menyebab menurut hubungan-hubungan asosiasi. Yang dimaksud dengan hubungan asosiasi adalah hubungan kesamaan, baik kesamaan waktu, wujud, totalitet dan bagian, serta persamaan bunyi. Unsur lain yang juga sangat penting dalam konsep magi adalah mantera.

Dalam penjelasannya lebih lanjut Frazer dalam Koentjaraningrat (1987) menyebutkan, bahwa ada dua macam magi sebagaimana dikemukakan oleh Frazer: (1) magic yaitu magi yang dilakukan berdasarkan anggapan bahwa suatu hal bisa menyebabkan hal lain yang ada hubungannya secara lahir. Contohnya sepotong kuku atau segumpal rambut milik seseorang dapat digunakan untuk memengaruhi orang tersebut dari jarak jauh. Apabila bagian tubuh atau benda yang pernah mengalami kontak fisik itu dihancurkan, orang tersebut menjadi sakit dan mati; (2) imitative magic, yaitu segala perbuatan untuk mencapai suatu tujuan dengan cara meniru. Misalnya seorang dukun mau mendatangkan hujan. Dukun itu mengucapkan mantera lalu ia disiram-siram dengan air, dengan maksud meniru hujan yang turun ke bumi, yang dalam konsep magi Koentjaraningrat bisa digolongkan ke dalam magi asosiatif.

Secara umum orang sering pula membedakan antara magi putih dengan magi hitam. Yang dimaksud dengan magi putih adalah penggunaan magi untuk tujuan-tujuan baik yang berguna dan menguntungkan masyarakat atau orang lain. Sedangkan magi hitam dipergunakan untuk tujuan jahat yang mendatangkan bencana dan kerugian bagi orang lain, atau untuk mencelakai orang lain. Di Indonesia, istilah yang lebih dikenal untuk magi hitam adalah guna-guna, santet, atau ilmu hitam.

Magi sering pula digunakan untuk meramalkan sesuatu yang berhubungan dengan kehidupan manusia sehari-hari. Contohnya, masyarakat Jawa bila akan 
melakukan suatu aktivitas penting, seperti perkawinan, membangun rumah, menanam padi, melakukan perjalanan jauh, dan sebagainya, biasa menggunakan petungan, yaitu perhitungan rumit yang termaktub dalam buku primbon.

\section{Religi}

Banyak konsep dan teori tentang religi dan asal mula religi yang telah disampaikan oleh para ahli antropologi dan ethnografi, antara lain: teori "Jiwa" atau "Evolusi Religi" E.B. Tylor (1873), teori "Batas Kemampuan Ilmu Gaib" dari J.G. Frazer (1890), teori tentang "Dewa Tertinggi" dari A. Lang (1844-1912), teori tentang "Kekuatan Luar Biasa" dari R.R. Marett (1909), teori "Masa Krisis dalam Hidup" dari M. Crawley (1905), teori "Sentimen Kemasyarakatan" dari Emile Durkheim (1912), dan masih banyak lagi teori-teori lainnya (lihat juga Syarif Moeis (2008). Koentjaraningrat merangkum semua teori itu dan mengklasifikasikannya pada 3 katagori, yaitu: (1) teori-teori yang dalam pendekatannya berorientasi pada keyakinan religi; (2) teori-teori yang dalam pendekatannya berorientasi pada sikap manusia terhadap alam gaib atau hal yang gaib; (3) teori-teori yang dalam pendekatannya berorientasi pada upacara religi.

Selanjutnya Koentjaraningrat (1987:54), mendefinisikan religi sebagai suasana batin bagi manusia untuk mencapai suatu maksud dengan cara menyandarkan diri pada kemauan dan kekuasaan makhlukmakhluk halus. Hal itu karena ada sangkutpautnya dengan kekuatan di luar batas kemampuan akal manusia yang disebutnya dunia gaib atau supernatural. Dunia gaib itu memiliki kekuatan luar biasa, artinya yang tak dapat diterangkan dengan akal. Jadi, segala hal yang berhubungan dengan kekuatan gaib itu sifatnya luar biasa.

Semua sistem religi, kepercayaan, dan agama itu berpusat pada suatu konsep tentang hal yang gaib (mysterium) yang dianggap mahadahsyat (tremendum) dan keramat (sacer) oleh manusia. Hal yang gaib atau yang keramat itu memiliki sifat- sifat yang tak terjangkau oleh akal dan pikiran manusia.

Kesadaran akan adanya kekuatankekuatan yang berada di luar batas kekuasaan dan kemampuan manusia (supernatural), telah lama dimiliki oleh masyarakat Sunda. Kesadaran ini muncul berbarengan ketika terdapat persoalanpersoalan hidup yang tidak dapat diatasi dengan kemampuan akal pikirannya. Dalam pengetahuan mereka kekuatan-kekuatan ini ada yang berasal dari arwah para leluhur karuhun, atau pun para dangiang, yaitu sebangsa makhluk gaib lelembutan yang diyakini dapat membantu mengatasi persoalan hidup yang tengah dihadapi. Makhluk-makhluk ini pun diyakini dapat memancarkan cahaya atau aura positif bagi yang menggunakannya.

Betapapun sederhananya suatu kelompok masyarakat pastilah mereka memiliki religi, karena religi merupakan unsur budaya yang selalu bercampur dan terjalin erat dengan aktivitas-aktivitas keagamaan dalam masyarakat. Inti religi adalah hal yang disakralkan oleh penganut agama itu, baik dalam menyembah maupun dalam kepercayaan.

\section{HASIL DAN BAHASAN}

1. Sekilas Gambaran Kabupaten Subang

Secara geografis Kabupaten Subang terletak di bagian utara Jawa Barat antara $6^{\circ} 11^{\circ}$ - Lintang Selatan dan $107^{\circ} 54^{\circ}$ Bujur Timur, dengan luas wilayah 205.176,950 ha, atau 4, 64\% dari luas keseluruhan wilayah Jawa Barat. Berdasarkan pembagian daerah administrasi, wilayah Kabupaten Subang terbagi atas 6 wilayah pembantu bupati, 20 kecamatan dan terbagi dalam 8 kelurahan dan 242 desa. Subang dikenal juga sebagai salah satu daerah yang berada di wilayah bagian jalur pesisir pantai utara (pantura) Jawa Barat, yang berbatasan langsung di sebelah utara dengan Laut Jawa, di sebelah timur dengan wilayah Kabupaten Indramayu dan Sumedang, di sebelah selatan dengan Kabupaten Bandung, dan di 
sebelah barat berbatasan dengan Kabupaten Purwakarta dan Karawang.

Secara geografis, Kabupaten Subang merupakan daerah yang beriklim tropis dan termasuk sebagai daerah agraris yang subur. Mata pencaharian utama sebagian besar masyarakat di daerah ini masih bergantung pada hasil pertanian. Sekalipun sekarang kondisinya sudah berubah dengan terdapatnya perindustrian, namun pertanian masih tetap merupakan andalan utama bagi kehidupan masyarakat.

Adapun macam profesi masyarakat Subang lainnya setelah masa kemerdekaan, antara lain: pegawai negeri sipil (PNS), TNI dan polisi, pegawai swasta dan wiraswasta menyangkut kegiatan usaha dagang, tani, nelayan, buruh pabrik, seniman, pembantu rumah tangga, dan lain sebagainya. Bermacam pekerjaan tersebut tidak hanya dikerjakan oleh kaum laki-laki, kaum perempuan pun banyak yang terlibat. Hal ini dilakukan dalam usaha membantu untuk menambah penghasilan keluarga. Jenis usaha yang dikerjakan tidak terpaku hanya dalam satu bidang pekerjaan saja, melainkan bisa merangkap, bergantung menurut mereka yang secara ekonomis dianggap menguntungkan.

Demikian pula halnya profesi sinden, dalam kenyataan tidak seluruhnya mengandalkan berprofesi sebagai penghibur saja, tetapi juga di luar panggung sebagai manusia biasa, mereka terlibat dengan pekerjaan lain seperti mengajar, mengurus rumah tangga, bertani, berdagang, mengurus salon, dan usaha lainnya. Dengan menjadi sinden berarti dapat dijadikan sebagai mata pencaharian untuk meningkatkan taraf hidup.

Kabupaten Subang merupakan salah satu daerah lumbung seni di wilayah Tatar Sunda. Hampir semua jenis kesenian Sunda hidup dan berkembang di daerah Subang. Sisingaan, wayang golek, kliningan, bajidor, gembyung dan toleat adalah jenis-jenis kesenian tradisional Sunda yang hingga kini masih banyak peminatnya di Kabupaten Subang.
Demikian pula seni tari tradisional dan kontemporer serta seni sinden tumbuh subur di daerah Kabupaten Subang. Khusus untuk seni sinden, Kabupaten Subang telah melahirkan cukup banyak sinden yang telah punya nama, seperti Titim Patimah, Mimin Mintarsih, Encem Sunariah, Enung Uar Suarsih, Cicih Cangkurileung, Aan Sayati alias Si Japati, dan masih banyak lagi sinden muda yang punya tempat di hati masyarakat Sunda.

\section{Asal-usul dan Perkembangan Sinden di Kabupaten Subang}

Kata sinden menurut Atik Soepandi (1988: 180) berasal dari kata sindi-an atau sindir-an, yang berarti rumpaka atau syair lagu. Sedang pelaku yang menyajikannya disebut pasinden, juru sekar, atau juru kawih. Nanu (2004: 211) menjelaskan pula bahwa yang dimaksud sinden itu adalah istilah untuk menamakan wanita penyanyi kawih dalam pertunjukan wayang golek atau kliningan. Lebih jauh Nanu menjelaskan bahwa munculnya istilah sinden tersebut sebenarnya adalah untuk mengganti istilah ronggeng, yaitu penyanyi wanita dalam pertunjukan wayang golek atau kliningan. Penggantian istilah itu dilakukan oleh beberapa kalangan seniman karena sebutan ronggeng dianggap identik dengan kehidupan wanita penggoda. Perubahan istilah ini merupakan hasil dari pertemuan yang diprakarsai, antara lain oleh $\mathrm{R}$. Aripin, Moch. A. Affandie, R. Partasuanda, dan Arnesah, pada tahun 1948.

Kemudian pada tahun 1955, R.A. Darya yang kala itu menjabat sebagai Kepala Siaran RRI Bandung, memprakarsai sawala atau musyawarah dengan para seniman-seniwati se-Jawa Barat. Hasil dari pertemuan tersebut muncul istilah juru sekar sebagai pengganti istilah sinden. Tampaknya dalam perjalanannya upaya penggantian istilah untuk menamakan penyanyi wanita itu terus berlanjut mengalami perubahan. Pada dekade 70-an muncul istilah juru 
kawih untuk menyebut sinden atau juru sekar. Penggantian istilah tersebut dimaksudkan untuk meningkatkan citra sinden di lingkungan masyarakat.

Ada tiga istilah atau sebutan terkait keberadaan sinden, yaitu: sinden ronggeng, sinden juru kawih, dan sinden tatandakan. Sinden ronggeng adalah sinden yang memiliki keahlian ganda, yaitu sebagai juru kawih (penyanyi) dan juga sebagai penari. Sinden juru kawih adalah sinden yang khusus sebagai penyanyi saja. Sedangkan sinden tatandakan adalah sinden yang lebih berfungsi sebagai penari. Sinden tatandakan ini sesungguhnya tidak memiliki keahlian menyanyi ngawih, akan tetapi di atas panggung ia ditempatkan sejajar dengan sinden juru kawih.

Mengenai perkembangan dunia sinden di daerah Subang, dipaparkan oleh Haryadi Suadi (1997) dalam sebuah tulisanya di Harian Umum Pikiran Rakyat. Menurut penuturannya, sejarah sinden di Jawa Barat telah berlangsung semenjak dulu, tepatnya semenjak tahun 1930-an. Tercatat nama Nyi Mene, seorang sinden yang mengangkat lagu Sorban Palid. Lagu ini direkam di atas piringan hitam yang kemudian mengangkat namanya sebagai seorang sinden terkemuka pada waktu itu. Pada tahun-tahun berikutnya bermunculan sinden-sinden baru, salah satunya adalah Nyi Warsih (1937) yang pada waktu itu terkenal dengan lagunya Leang-leang dan menjadi top hit di radio NIROM Bandung pada waktu itu.

Di daerah Subang sendiri menurut penuturan seorang pemerhati kesenian tradisional, Idit Spriadi, ada nama Nyi Sukarsih yang merupakan sinden pertama yang suaranya direkam dengan piringan hitam yang diproduksi oleh PT Philip Belanda, sekitar tahun 1930-1940-an. Lagu yang direkam berisi lagu-lagu gede yang berirama lambat. Lagu tersebut dikenalkan kepada masyarakat bersamaan dengan lagu sinden lainnya yang disiarkan lewat radio Palide, studio lokal yang berada di daerah Subang pada waktu itu.
Periode selanjutnya, sekitar tahun 1950-an hingga awal 1960-an muncul sinden yang bernama Titim Fatimah. Beliau dilahirkan di Deli Serdang, Sumatera Utara, dan dibesarkan di Desa Jalan Cagak Kabupaten Subang. Titim adalah seorang sinden yang meniti karier sinden dari kampung ke kampung hingga hijrah ke Kota Bandung, dan selanjutnya hijrah ke Jakarta higga ia meninggal di sana.

Titim Fatimah dengan lagu cahya sumirat dan beberapa lagu lainnya, seperti tongtolang nangka, kulu-kulu gancang, dan cangkurileung, telah mengorbitkan namanya menjadi seorang sinden yang terkenal, hingga akhirnya mencapai puncak kariernya. Pada zamannya, kepopuleran Titim Fatimah hampir menyamai kepopuleran sinden pendahulunya, yaitu Upit Sarimanah (Rosidi, 1999: 450).

Regenerasi sinden di daerah Subang tidak berhenti sampai di situ. Pada tahun 1960-an bermunculan sinden-sinden baru yang memiliki kemampuan menyanyi tidak kalah dari Titim Fatimah. Akan tetapi kemunculan mereka lebih dikenal di seputar lingkungan lokal Subang, sekalipun di antara mereka ada yang namanya dikenal di luar daerah Subang. Sinden-sinden yang dikenal di daerah Subang pada masa itu antara lain sinden Juju Juariah dan R. Encem Sunariah. R. Encem bahkan pernah meraih prestasi sebagai sinden I terbaik dalam Binojakrama Pedalangan Se-Jawa Barat dan DKI Jaya.

Pada tahun 1964, tatkala gejolak politik sedang memanas, ketika itu dibentuk suatu perhimpunan juru kawih yang diprakarsai oleh Ny. Oetje Djungdjunan. Berdirinya organisasi tersebut pada mulanya bertujuan untuk merekatkan persatuan para pesinden di daerah Subang. Di balik itu sebenarnya penguasa setempat, Pemerintah Daerah Kabupaten Subang bersama militer, juga mempunyai maksud tertentu, yaitu untuk melindungi para pesinden agar tidak 
dipengaruhi oleh organisasi politik tertentu (yang dianggap laten). Degan kata lain, agar sinden tidak dijadikan sebagai alat propaganda politik. Nama dari organisasi juru kawih tersebut yaitu Paguyuban Juru Kawih Kabupaten Subang. Sinden Cucun Cunayah pada waktu itu diangkat sebagai ketua paguyuban, didampingi oleh wakil ketua R. Encem Sunariah.

Pada tahun 1964-an hingga 1970-an terjadi perkembangan pada kesenian kliningan, yaitu dipopulerkannya jenis kesenian kliningan bajidor. Jenis kesenian ini bisa mewadahi kaum bajidor untuk menyalurkan kegiatan menari bebasnya. Yang berperan penting pada penampilan kesenian ini adalah sinden.

Pada periode ini muncul sindensinden seperti: Uas, Juju Juarsih, kemudian Utik, Ucit, Titi Juarti, dan berlanjut ke Cucun, Nani Suryani, juga menyusul Cicih Cangkurileung. Mereka masing-masing memiliki ciri dan gaya dengan penampilan yang khas, yaitu ada yang cenderung menjadi sinden-ronggeng, ada pula yang menjadi sinden-kawih. Pada masa ini penyajian lagu lebih diutamakan.

Di awal tahun 1980-an, muncul kesenian jaipongan, yang merupakan perkembangan dari kesenian kliningan bajidoran. Munculnya jaipongan, membawa beberapa perubahan pada penyajian kiliningan-bajidoran, yang ditandai dengan adanya ibing pola, yaitu ibingan (tarian) jaipong berdasarkan gerak yang sudah dipola berpatokan pada suatu lagu tertentu. Adanya ibing pola ini mewarnai penampilan sinden dengan ibingan tunggal yang disajikan secara khusus sebagai pembuka pada setiap pertunjukannya. Ibingan pembuka ini bisa dibawakan oleh sinden itu sendiri, bisa juga dibawakan oleh penari khusus. Demikian pula di panggung yang berjejer tidak hanya sinden ronggeng, dan sinden juru kawih, namun pada masa ini mulai pula adanya penari yang disebut sinden tatandakan.

\section{Fenomena Sinden di Kalangan Masyarakat Subang.}

Tidaklah mudah menjadi seorang sinden. Profesi sinden adalah profesi seorang entertain di bidang tarik suara. "Hidup matinya" seorang sinden sangat ditentukan oleh bagaimana kemampuannya dalam mengolah suara, dan yang tidak kalah pentingnya ialah penampilannya di atas panggung. Melalui kemampuan olah vokal dan olah tubuhnya, sinden berinteraksi langsung dengan penikmatnya. Oleh sebab itu keberhasilan seorang sinden sangat ditentukan oleh kemampuan dia dalam menghibur dan memikat para penikmatnya.

Oleh karena itu pula, untuk menjadi seorang sinden dituntut beberapa kemampuan dasar, di samping bakat. Adapun modal dasar yang harus dimiliki untuk menjadi seorang pesinden adalah sebagaimana dikemukakan oleh Barnas Somantri (1992: 3), bahwa aspek yang paling pokok atau mendasar secara tradisi yang harus dimiliki sinden adalah modal suara, lagu, dan rupa. Hal senada dikemukakan oleh Mas Nanu Munajar (2004: 161) mengutip hasil wawancaranya dengan seorang guru sinden, Eutik Muhtar, yang menyatakan bahwa syarat sakudratna (seutuhnya) menjadi sinden harus memiliki kemampuan antara lain sae senggolna, rupa, jeung lagu (bagus suaranya, rupa, dan lagu). Ketiga syarat tersebut merupakan modal utama yang harus dimiliki sinden. Dengan kata lain, senggol, rupa, dan lagu, sesungguhnya merupakan ajen (nilai) yang harus dimiliki sinden di dalam dunia seni sinden.

Pengertian senggol disampaikan oleh Atik Soepandi (1988:183), menurutnya senggol adalah komposisi nada tertentu untuk mengisi rangkaian lagu yang dibawakan oleh juru sekar. Selanjutnya, R. Encem Sunariah, dalam wawancaranya dengan Mas Nanu Munajar di tahun 2000 mengemukakan bahwa senggol merupakan suatu pembawaan yang diciptakan dari hasil kreativitas yang ditemukan dalam menyinden yang rasa 
enaknya bergantung pada sinden itu sendiri. Atau dengan kata lain, pada pokoknya sinden itu sendirilah yang menciptakan senggol tersebut. Senggol ini menjadi kekuatan yang utama dari seorang sinden dan sekaligus menjadi ciri khas yang memberikan identitas bagi dirinya, hingga secara sekilas saja orang (pendengar) dapat membedakan bahwa ini adalah suara sinden tertentu. Senggol dapat pula diartikan sebagai gaya yang dimiliki oleh sinden secara pribadi, ataupun gaya khas suatu daerah.

Modal dasar yang kedua adalah rupa. Yang dimaksud dengan rupa di sini adalah paras atau aura yang dipancarkan oleh seorang sinden melalui penampilan paras mukanya dan menjadi daya tarik bagi penontonnya. Akan tetapi bukan berarti bahwa untuk menjadi seorang sinden haruslah mempunyai paras yang cantik, karena cantik itu sendiri sangatlah relatif. Yang penting dari rupa seorang sinden itu adalah bisa membuat penonton menjadi terpikat dengan aura yang terpancar dari parasnya. Untuk mendapatkan daya tarik dari rupa ini tidak jarang seorang sinden harus menggunakan pamake, yaitu sesuatu barang/benda yang secara magis bisa menimbulkan aura bagi seseorang.

Modal dasar yang ketiga adalah lagu. Menurut Atiek Soepandi (1988:110), lagu adalah nada yang disusun sedemikian rupa, sehingga indah dan enak didengar. Lagu terdiri atas rangkaian kalimat, atau yang dalam bahasa Sunda disebut rumpaka yang disusun secara berirama dan bermelodi.

Satu modal lagi yang tidak kalah pentingnya, bahkan menjadi modal utama bagi seorang sinden adalah sora (suara). Modal suara ini biasanya diperoleh melalui bakat, namun bisa juga diperoleh melalui latihan. Artinya bila dasar suaranya memang tidak bagus, sumbang atau rebek (suaranya pecah), betapa pun kerasnya dia berlatih, tetap saja tidak akan memiliki suara yang merdu dan enak didengar. Bagi Sinden, suara merupakan hal yang paling pokok harus dikuasai dan harus diolah, dilatih, diasah sehingga ia bisa memiliki suara yang indah dan merdu. Bila modal suara ini sudah dimiliki maka ia bisa membawakan lagu-lagu dengan indah, merdu, serta enak didengar. Sinden yang tanpa memiliki modal suara, tetapi hanya mengandalkan rupa cantik dan kemampuan menari saja digolongkan juga sebagai sinden, dengan sebutan sinden tatandakan.

Di dalam konteks kemasyarakatan, sinden adalah warga sebuah kelompok masyarakat. Ia hidup dan beraktivitas di tengah-tengah keberadaan orang lain di sekitarnya, atau dengan kata lain di dalam lingkungan sosialnya yang telah memiliki perangkat tata nilai yang mengatur kehidupan masyarakat tersebut. Lingkungan ini lazim disebut sebagai lingkungan budaya. Dalam konteks ini, seni, termasuk seni sinden dibentuk oleh lingkungan di mana seniman itu berada.

Burke (2001:177) menyatakan bahwa seni itu dibentuk oleh lingkungan sosialnya. Artinya bahwa lingkungan sosial budaya di mana seniman itu hidup akan menentukan corak dan perkembangan dari kesenian, yang pada gilirannya akan memengaruhi perkembangan seni itu sendiri. Demikian pula halnya dengan sinden, sinden sebagai seorang seniman, sekaligus sebagai warga suatu masyarakat, dibentuk oleh lingkungan budayanya. Sinden pun dapat memengaruhi perkembangan kesenian di dalam lingkungan masyarakat di mana sinden itu hidup dan beraktivitas. Dengan demikian, sinden memiliki keterikatan yang tidak dapat dihindarkan dengan lingkungan masyarakatnya, karena perilakunya dalam banyak hal ada keterikatan dengan masyarakat dan budaya.

Selain sebagai warga suatu kelompok masyarakat, sinden pun adalah anggota sebuah keluarga. Sebagaimana diketahui bahwa keluarga inti merupakan kesatuan sosial terkecil, akan tetapi memiliki peran yang sentral dalam pembentukan, pertumbuhan, dan perkembangan anggota keluarga. Berawal dari keluarga inti inilah seseorang terjun ke masyarakat, sebagai anggota masyarakat, 
dan di dalam lingkungan masyarakat itu, seseorang menentukan langkah hidupnya ke depan, mau ke mana dan mau jadi apa dia selanjutnya. Dalam konteks ini, menjadi sinden adalah sebuah pilihan hidup.

Sebagai anggota sebuah keluarga, tentu saja di dalam keluarga tersebut terdapat pranata-pranata yang mengatur fungsi dan peran masing-masing anggota keluarganya. Bagi sinden yang sudah berkeluarga, terlebih yang sudah mempunyai anak, melakukan pekerjaanpekerjaan rumah dan mengasuh anak adalah tetap menjadi tugas utamanya. Kendatipun ia sudah bisa menghasilkan uang dari profesinya sebagai seorang sinden, akan tetapi tanggung jawab utamanya tetap di dalam mengerjakan pekerjaan-pekerjaan rumah tangga. Adapun yang bertanggung jawab penuh dalam menafkahi dan menyejahterakan keluarga lahir dan batin adalah suaminya. Dalam hal ini suamilah yang bertanggung jawab secara ekonomi, sosial dan budaya. Tanggung jawab suami dalam hal ekonomi tercermin dalam pelimpahan seluruh atau sebagian penghasilan suami kepada istri, dan istrilah yang berperan dalam mengatur dan mengelola keuangan keluarga.

Dalam kaitan ini, Ieke Sartika Iriane dalam sebuah tulisannya di Harian Umum Pikiran Rakyat 4 Oktober 2001, mengatakan bahwa: "Orientasi perempuan Sunda hanya tertuju pada upaya untuk mendapat uang untuk peningkatan kualitas kebutuhan keluarga, bukan pada pencapaian karier yang tinggi". Pada umumnya sinden di Subang juga memiliki pandangan yang sama. Mereka bekerja nyinden bukan sebagai pencari nafkah utama di dalam keluarga, melainkan untuk mencari tambahan penghasilan bagi keluarga guna meningkatkan kualitas kehidupan ekonomi keluarganya.

Pada umumnya para sinden di Subang, berangkat dari hobi, tidak secara khusus belajar menyinden sebagai bekal untuk mencari nafkah. Namun dalam perkembangannya kemudian, karena sang sinden sudah mengenal uang, maka orientasinya pun berubah. Ia tidak sekadar melampiaskan hobi atau kegemaran semata, melainkan juga untuk mendapatkan penghasilan.

Fenomena di lapangan ketika penelitian ini dilakukan, terjadi beberapa kasus terkait dengan penghasilan istri (sebagai sinden) yang lebih besar ketimbang penghasilan suami.

Kasus pertama, suami merasa diuntungkan dan terkadang kurang mempunyai rasa tanggung jawab, sehingga sebagian besar atau sepenuhnya tanggung jawab keluarga dalam mencari nafkah berpindah ke pundak istri sebagai sinden. Dengan demikian tugas istri semakin berat, di samping ia harus memenuhi tugas utamanya sebagai ibu rumah tangga, ia juga harus mencari nafkah untuk menghidupi keluarganya. Dalam kasus ini peranan istri menjadi ganda.

Kasus kedua, istri yang merasa mempunyai penghasilan lebih besar daripada suami, menjadi "besar kepala" dan merendahkan martabat suaminya. Sebutan kepada si istri yang berkelakuan demikian, dalam istilah setempat disebut unggah adat, yang maksudnya perilakunya berubah menjadi sombong dan merendahkan suami.

Kasus ketiga, suami merasa termotivasi untuk lebih giat lagi mencari nafkah agar tidak kalah oleh istrinya.

Kasus yang pertama dan kedua seringkali menjadi pemicu terjadinya konflik di dalam rumah tangga. Hubungan suami dengan istri menjadi tidak harmonis. Tidak jarang hal demikian berujung pada perceraian. Lain halnya dengan kasus yang ketiga, ini justru mendorong keluarga tersebut untuk bahu-membahu berusaha mencari nafkah agar hidup lebih sejahtera secara finansial dan bisa meningkatkan derajat keluarganya di dalam lingkungan masyarakatnya.

Bagi sinden yang berstatus sebagai istri, kemampuannya memeroleh penghasilan dari menyinden, tidaklah untuk menjadi pesaing bagi suami dalam 
mencari nafkah. Mereka melakukannya hanya untuk menambah 'resiko dapur'. Apa yang dilakukannya itu adalah sebagai bentuk pengabdian dan pengorbanan demi keluarganya sendiri.

Latar belakang ekonomi sebagian besar sinden Subang adalah dari kalangan ekonomi menengah ke bawah. Umumnya suami mereka bekerja sebagai petani, pedagang, tukang, dan ada juga yang pegawai kantor (PNS). Kehidupan ekonomi rumah tangga mereka kebanyakan tidak dapat dipenuhi dengan hanya mengandalkan penghasilan suami saja. Dengan menyinden, mereka memeroleh tambahan penghasilan sehingga kehidupan rumah tangga bisa lebih sejahtera. Di samping itu juga memberikan banyak peluang dan kebebasan pada mereka untuk mengembangkan diri.

Sinden yang sudah bisa mencari nafkah hingga berhasil dan mandiri, akan mampu meningkatkan status sosialnya di masyarakat. Para pesinden tidak pernah mempertentangkan perbedaan perempuan dan laki-laki (suami) dalam memenuhi kebutuhan keluarganya. Dalam hal ini, tujuan yang utama adalah membantu meringankan beban ekonomi suami atau keluarga, serta meningkatkan harkat derajat keluarga dan orang tua di mata masyarakat.

Terkadang pekerjaan rumah tangga dirasa begitu berat, apalagi jika harus merangkap sebagai sinden juga. Namun demikian, tugas rumah tangga itu sebagai kewajiban utama yang harus dijunjung tinggi dan dilakukan dengan perasaan senang. Justru pekerjaan rumah tangga itu seperti dikatakan Lise Vogel dalam Megawangi, (1999:114), adalah pekerjaan yang menyenangkan, memberikan peluang untuk lebih kreatif, serta merasakan langsung semua produk yang dihasilkannya dan miliknya sendiri.

\section{Fenomena Penggunaan Magi}

Masyarakat Subang mengenal beberapa konsep berkenaan dengan keberadaan makhluk halus dan penggunaan atau pemanfaatan daya-daya magis, di antaranya adalah:

\section{a. Dangiang}

Dalam kamus Basa Sunda dijelaskan bahwa kata dangiang berasal dari kata danghyang, yaitu bangsa lelembutan atau dedemit (makhluk gaib) yang menjadi penguasa di suatu rumah atau suatu kampung. Menurut Suparlan (1988:29), kata dangiang itu asalnya dari dhanghyang yang artinya pendeta. Kata dhangyang ialah panggilan kepada para pendeta atau hantu pelindung.

Pada kalangan masyarakat Subang, khususnya pada kalangan seniman, konsep dangiang ini diinterpretasikan sebagai makhluk gaib yang dapat memberikan bantuan serta perlindungan kepada manusia. Makhluk ini pun diyakini dapat memberikan kekuatan dan memantulkan cahaya berupa aura positif terhadap diri pemakainya. Cahaya yang dipancarkannya ini dapat memberikan kekuatan daya tarik, sehingga orang yang melihatnya menjadi tertarik dan terpesona. Di samping itu, mereka pun meyakini bahwa kekuatan dangiang ini dapat mentransfer ilmu maupun keahlian, baik dalam bidang seni suara (seni sinden), kemampuan dalam menari (bagi para penari), maupun kepiawaian dalam menabuh atau memainkan waditra (peralatan musik gamelan). Bagi para pesinden, kekuatan dari makhluk dangiang ini dapat menjadikan suara sinden menjadi merdu, penuh daya tarik dan daya pikat. Demikian pula terhadap para penari, kekuatan ini dapat memberikan kepiawaian dalam olah tubuh, gerakan-gerakan tari yang menawan.

Dangiang di kalangan para seniman tradisional di daerah Subang dipercaya menjadi salah satu faktor pendukung bagi suksesnya karier seseorang. Ia mampu memberikan aura kuat yang akan mengangkat derajat hidup dan pamornya di mata masyarakat. Untuk mendapatkan aura ataupun kekuatan dari dangiang tersebut, diperlukan upaya yang tidak 
ringan, dan biasanya tidak dilakukan sembarang waktu.

Ada waktu-waktu dan tempattempat khusus yang dianggap tepat dan "mujarab" untuk melakukan perburuan dangiang, yaitu biasanya pada malam Selasa atau Jumat Kliwon. Bulannya pun tertentu, yaitu bulan Muharam dan Maulud yang dipandang sebagai hari dan bulan yang baik untuk melakukan ritual. Tempatnya pun tidak sembarangan, melainkan harus di tempat khusus yang oleh masyarakat umum biasanya dipandang sebagai tempat yang sakral.

Fenomena ritual untuk mendapatkan kekuatan dan kemampuan dari dangiang ini sudah lazim pada kalangan seniman tradisi di Subang. Bagi seniman (sinden) maupun kalangan masyarakat (penggemar) kliningan-bajidoran, dangiang dipercaya memiliki kekuatan gaib yang dapat memancarkan aura dan daya tarik yang kuat untuk mengharumkan nama, penampilan dirinya, maupun grupnya Maka, tidak heran jika setiap group kliningan-bajidoran khususnya sinden, selalu mengharapkan ketitisan dangiang atau lelembutan yang pada gilirannya dapat meningkatkan "pasaran" mereka di dunia seni pertunjukan. Dampak lebih lanjutnya adalah mampu meningkatkan taraf pendapatan mereka.

\section{b. Pamake}

Dalam Kamus Umum Basa Sunda, pamake atau aji pamake diartikan sebagai: ajian pikeun ngaganggu diri atawa ingetan batur, saperti teluh, wisaya, pelet, jeung saterusna (ilmu batin untuk mengganggu pikiran orang lain, seperti teluh (santet), wisaya (mantera untuk mencelakakan orang lain, pelet, dan sebagainya).

Pada kalangan masyarakat seniman, tradisi di Kabupaten Subang, pamake dikiaskan sebagai ilmu kebatinan, berupa energi spiritual yang dapat memancarkan aura, daya pesona yang kuat yang memancar dari si pemakainya. Energi ini bisa diimplementasikan melalui benda, jampi-jampi atau mantera, ataupun perbuatan. Pada hakikatnya pamake adalah segala sesuatu (barang, mantera) yang diisi dengan suatu kekuatan magis dari yang gaib guna mencapai tujuan tertentu.

Berdasarkan fungsinya, pamake dapat dikategorikan ke dalam 5 jenis, yaitu: kinasihan, pangirutan, pangambaran, gendam, dan bungkeman.

- Kinasihan, adalah benda atau pun mantera yang khasiatnya untuk menimbulkan daya tarik dan daya pikatdari pemakainya;

- Pangirutan untuk menarik hati supaya disayangi, tujuannya adalah untuk menjerat massa (penonton);

- Pangambaran adalah ilmu untuk mendapatkan aura atau pamor, yang tujuannya adalah untuk menutup nafsu atau mendiamkan orang (masa);

- Gendam, yaitu ilmu atau ajian supaya dicintai, disayangi dan dikasihi, mencakup pelet untuk persahabatan, silaturahmi, dan pergaulan.

- Bungkeman adalah suatu ilmu untuk menutup mulut orang lain, khasiatnya untuk membungkam penonton menjadi terkesima sampai diam dan terpesona.

Dari kelima jenis pamake tersebut, pada umumnya sinden Subang lebih banyak menggunakan jenis pamake yang berhubungan dengan kinasihan.

Nanu Munajar (2004: 174) menguraikan dua cara untuk memperoleh pamake atau kekuatan magis, yaitu ngalomah dan ngagandek. Ngalomah adalah cara-cara untuk memperoleh kekuatan magis, baik berupa pamake ataupun ilmu kebatinan, yang diperoleh dengan usaha sendiri melalui zikir, puasa dan melakukan pantangan-pantangan tertentu. Cara ngalomah ini harus dilakukan sendiri oleh yang punya maksud, tidak boleh diwakilkan kepada orang lain ataupun melalui perantara. Pantangan yang utama bagi yang ngalomah ialah, ia tidak boleh berbuat maksiat. Artinya ia tidak boleh melakukan hal-hal yang dilarang etika dan akidah agama (Islam), misalnya berzinah. Apabila pantangan ini dilanggar, maka diyakini ilmunya akan menjadi 
cambal (ilmu dan kekuatan gaibnya tidak mujarab lagi).

Adapun ngagandek adalah cara memeroleh kekuatan magis ataupun ilmu gaib dengan cara menempel pada jin atau makhluk halus yang menjadi kematannya atau yang dipujanya. Dalam Kamus Basa Sunda, gandek diartikan sebagai panakawan, bujang, badega, yaitu orang yang menjadi pengiring atau pembantu. Dalam hal ini, orang yang melakukan ngagandek menyandarkan diri pada kekuatan-kekuatan magis atau pun makhluk-makhluk gaib untuk dapat memancarkan kekuatan magisnya.

Ada berbagai ragam pamake yang biasa digunakan oleh para sinden di Subang, antara lain susuk, parabot (jimat), dan jampi atau mantera.

Susuk adalah suatu benda berupa emas atau perak yang sudah dimanterai kemudian dimasukkan atau dibenamkan ke dalam tubuh dengan maksud agar mendapatkan kesaktian atau untuk menimbulkan daya tarik. Di kalagan para sinden, susuk ini biasanya dibenamkan di bawah kulit kening, pipi, dagu, pinggul, dada, dan ada juga yang di tangan. Bagi para sinden, penggunaan susuk ini tujuannya ialah untuk menimbulkan daya tarik, agar kelihatan cantik, menarik, dan mempesona. Susuk ini bahannya ada yang terbuat dari emas, berlian, dan intan. Dari ketiga bahan tersebut, yang dianggap paling bagus dan berkualitas adalah dari bahan intan.

Parabot, atau sering juga disebut jimat adalah benda yang dipandang mengandung kekuatan magis. Adapun benda-benda yang biasa dijadikan parabot tersebut di antaranya: keris, alat kecantikan, ikat pinggang, konde, isim, batu wulung, rokok dengan kemenyan. Benda-benda ini diisi dengan kekuatan magis untuk menimbulkan efek magis. Khusus untuk peralatan kecantikan, ritualnya dilakukan pada saat sinden itu dirias atau sebelum pertunjukan. Peralatan kecantikan yang sudah diisi dengan kekuatan magis tidak boleh dipinjamkan kepada orang lain. Begitu pula yang memakai minyak wangi (parfum), ritual memakai minyak wangi-wangian sama seperti memakai alat kecantikan dilakukan sebelum pertunjukan dimulai. Minyak tersebut bisa disemprotkan pada busana (kebaya) atau dioleskan di sekitar alis (mata, kening, bulu mata), biasanya yang sudah lazim di sekitar alis mata sinden. Fungsi minyak selain untuk mewangikan tubuh dan pakaian (busana), juga untuk memancarkan daya tarik. Persyaratan lain, minyak wangi yang telah dijampi itu tidak boleh dipakai oleh orang lain selain sinden itu sendiri.

Benda lainnya yang biasa dijadikan sebagai pamake adalah isim, yaitu kertas yang sudah ditulisi aksara Arab dan telah diberi doa/mantera, lalu dibungkus dengan kain warna putih. Kalimat-kalimat yang ditulis pada isim tersebut mengandung makna tertentu yang hanya dimengerti oleh dukun yang membuatnya. Adapun sinden yang memakainya hanya dapat merasakan khasiat dari isim tersebut, tanpa mengerti maknanya. Fungsi isim bisa bermacammacam bergantung pada kepentingannya, ada yang untuk daya tarik, kewibawaan, dan juga keselamatan. Namun bagi sinden biasanya menggunakan isim adalah untuk menimbulkan daya tarik dan kewibawaan.

Khasiat dari berbagai jenis parabot tersebut, akan memberikan efek magis dari benda itu yang pengaruhnya akan terasa apabila dipergunakan di panggung. Parabot itu akan memancarkan suatu energi pada pribadi yang memakainya yang kemudian tampil menjadi lain.

\section{c. Dukun}

Satu faktor lagi yang tidak dapat dipisahkan dari keberadaan sinden dan penggunaan magi (kekuatan gaib) adalah dukun. Bagi masyarakat Subang, dukun mempunyai arti yang sangat penting, khususnya bagi kalangan sinden. Bagi masyarakat Subang, dukun adalah orang yang cukup dihormati dan dianggap sebagai orang yang memiliki kemampuan luar biasa dalam hal ilmu gaib. Peranan 
dukun bukan hanya menyangkut perihal penyembuhan dan peramalan, melainkan juga berperan sebagai perantara atau mediator antara manusia dengan yang gaib. Di samping itu dukun pun dipandang sebagai orang yang memiliki kekuatan gaib yang dapat ditransfer melalui mantera, benda-benda parabot, dan ritual tertentu untuk digunakan oleh orang yang membutuhkannya (pasien atau client). Dukun pun diyakini memiliki kemampuan memberikan "kesaktian" kepada yang membutuhkan, baik berupa kinasihan, pelet, perjodohan, perhitungan hari baik, santet maupun kekuatan-kekuatan lain yang bersumber dari dunia gaib.

Dukun, kiai, kuncen, atau paranormal, oleh para sinden di daerah Subang pada umumnya dijadikan sebagai tempat meminta pertolongan untuk mencari solusi atas persoalan hidupnya, terutama untuk kepentingan meningkatkan eksistensi dan kepercayaan diri di atas panggung dengan memanfaatkan kekuatan supranatural.

Seorang dukun biasanya mempergunakan kekuatan-kekuatan dan kaidah gaib yang ada di dalam alam. Sinden, seperti orang Sunda lainnya, percaya akan adanya kekuatan gaib atau magis yang dimiliki dukun yang dapat memancarkan pengaruh yang baik maupun yang buruk (Ekadjati, 1995:294)

Tidak sedikit sinden di daerah Subang yang memanfaatkan jasa dukun untuk mencapai popularitas. Bagi kebanyakan masyarakat Subang, datang ke dukun, ke kiai atau pun berziarah ke makam-makam leluhur sudah menjadi bagian dari pola budayanya. Seringkali mereka mencari solusi mengatasi persoalan hidup yang dianggap cukup berat dan pelik dan di luar batas kemampuan akalnya, mereka lari ke dukun atau kiai. Dari dukun dan kiai itu lah mereka merasa mendapatkan jalan terang dalam upaya mengatasi persoalan hidupnya. Dengan kata lain, bagi kebanyakan masyarakat di daerah Subang, pergi ke dukun atau ke kiai dan "orangorang pintar" sudah menjadi bagian dari sistem religi mereka.
Alasan mereka berdukun, khususnya para sinden pada umumnya adalah untuk kepentingan ingin popularitasnya menanjak dan penampilannya disenangi, tetap terlihat cantik dan menarik, serta suaranya terdengar merdu, agar banyak yang mengundang pentas. Jadi, tujuan dari semua yang berdukun adalah untuk meminta diisi" untuk dijadikan sebagai pamake.

Ada dua cara yang biasa dilakukan untuk mendapatkan tenaga gaib dari dukun, yaitu: pertama hanya meminta pamake, baik berupa do'a, ataupun berupa parabot (benda) isim, susuk, dengan cara benda-benda tersebut sudah diolah oleh dukun, sinden hanya tinggal memakainya saja. Cara yang kedua adalah pasen (sinden) sendiri yang melakukan upaya "pengisian" tenaga gaib, melalui cara puasa, zikir, ataupun ritual tertentu di bawah bimbingan dan arahan dukun atau kiai. Kedua cara ini dipandang efektif oleh para sinden, seingga banyak sinden di Subang yang memanfaatkan jasa dukun, kuncen, ataupun kiai untuk memeroleh kekuatan gaib guna melancarkan profesinya sebagai seorang sinden.

\section{PEN UTUP}

Seni sinden adalah salah satu bagian dari kesenian. Kesenian itu sendiri merupakan salah satu unsur dari kebudayaan. Di antara ketiganya, yaitu seni sinden, kesenian dan kebudayaan terdapat hubungan struktural dan fungsional. Dengan demikian, perkembangan dunia seni sinden dipengaruhi oleh kondisi sosial budaya masyarakat di lingkungannya. Artinya, maju mundurnya dunia seni sinden bukan semata-mata persoalan pribadi-pribadi sinden, melainkan terkait dengan persoalan lingkungan budayanya.

Di kalangan para seniman tradisi Sunda, Kabupaten Subang dikenal sebagai "lumbung" sinden. Cukup banyak "sinden beken" yang muncul dari daerah ini. Kendatipun sebagian besar masyarakat Subang adalah penganut agama Islam, 
akan tetapi dalam kehidupan kesehariannya masih sangat erat dengan tradisi-tradisi yang diwarisi dari para leluhurnya. Termasuk dalam hal ini adalah kehidupan religi mereka yang memercayai adanya kekuatan-kekuatan gaib yang bisa dimanfaatkan untuk berbagai kepentingan. Satu di antaranya ialah kepentingan meningkatkan karier dan profesi di bidang seni sinden. Berbagai media dan cara pun ditempuh oleh para sinden untuk memeroleh kekuatan gaib tersebut guna meningkatkan popularitas mereka di atas panggung, yang pada akhirnya bisa meningkatkan taraf hidup mereka melalui dunia seni sinden.

\section{UCAPAN TERIMA KASIH}

Ucapan terima kasih disampaikan kepada:

1. Abah Nanu Munajar dosen STSI yang telah memberikan data yang sangat berarti bagi penulisan ini.

2. Mamah Mimin Mintarsih, Ketua Sanggar Seni Sinden Subang, yang telah bersedia diwawancarai.

3. Mamah Enung Uar Suwarsih, Ketua Sanggar Seni Kliningan Bajidor "Giler Kameumeut" yang telah memberikan informasi mengenai dunia sinden.

\section{DAFTAR SUMBER}

\section{Makalah}

Arthur S. Nalan. "Banyak Catatan” Untuk Seni Pertunjukan Milik Kita Sebagai Bangsa: dari Strategi Kebudayaan sampai Strategi Kesenian". Makalah disampaikan pada Kongres Kebudayaan Indonesia, Bogor $10-12$ Oktober 2008.

Barnas Somantri. "Napak Tilas Sela-sela Kahirupan Upit Sarimanah”. Kertas Makalah Saresehan Mengenang Jasa Ibu Hajah Upit Sarimanah di Bandung, 30 Oktober 1992.

Munajar, Mas Nanu, 2004

Sinden Kabupaten Subang, Jawa Barat. Suatu Kajian tentang Realitas Perjalanan Ulang-alik Kehidupan Sinden dalam Timbal - Balik. Tesis. Yogyakarta, Program Pasca Sarjana
Universitas Gajah Mada.

Syarif Moeis, 2008. "Religi Sebagai Salah Satu Identitas Budaya (Tinjauan Antropologis terhadap Unsur Kepercayaan dalam Masyarakat)". Makalah Disajikan dalam Diskusi Jurusan Pendidikan Sejarah FPIPS UPI Bandung.

\section{Buku}

Bagdan R.C \&Wilken S.R. 1986. Qualitative Research for Education and Introduction to Theory and Method. London, Allyn \& Bacon Inc.

Beatty, Andrew. 2001.

Variasi Agama di Jawa, Suatu Pendekatan Antropologi. Terjemahan oleh Achmad Fedyani Saefudin. Jakarta: Raya Grafindo Persada.

Burke, Peter. 2001. Sejarah dan Teori Sosial. Terjemahan oleh Mestika Zed dan Zulfami. Jakarta: Penerbit Yayasan Obor Indonesia.

Ekadjati, Edi S. 1995.

Kebudayaan Sunda, Suatu Pendekatan Sejarah. Jakarta: Pustaka Jaya.

Geertz, Clifford. 1989.

Abangan, Santri Priyayi dalam

Masyarakat Jawa. Terj. Aswab

Mahasin. Jakarta: Dunia Pustaka Jaya.

Koentjaraningrat. 2002.

Pengantar Ilmu Antropologi. Jakarta:

Rineka Cipta.

1990.

Beberapa Pokok Antropologi Sosial. Jakarta: Dian Rakyat, cetakan ke-7.

1987.

Sejarah Teori Antropologi I. Jakarta: Universitas Indonesia (UI PRESS), Cetakan Kedua.

Nasution, S. 1998.

Metode Penelitian Naturalistik

Kualitatif. Bandung: Penerbit Tarsito.

P.H. Embuiru. 1979.

Marga Bahagia. Penerbit Nusa Indah. Ende - Flores.

Pals, Daniel. 2001. Seven Theories of Religion: Dari Animisme E.B. Tylor, Materialisme Karl Marx Hingga Antrolologi Budaya 
C.Geertz. Alih Bahasa Ali Noer Zaman. Yogyakarta: Pnerbit Qalam.

Prawiroatmojo, S. 1989.

Bausastra Jawa-Indonesia Cetakan 4.

Jilid II. Edisi ke-2. Jakarta: Haji

Masagung.

Ratna Megawangi. 1999.

Membiarkan Berbeda? Sudut Pandang

Baru Tentang Relasi Gender. Bandung: Mizan.

Rosidi, Ajip. 1999.

Dalang Abor dalam Panggung Sejarah. Persembahan Kepada Prof. Dr. Denys Lombard, Ed. Henri Chambert-Loir dan Hasan Muarif Ambary (Jakarta: Ecole francaise d'Extreme-Orient, Pusat Penelitian Arkeologi Nasional. Jakarta. Yayasan Obor Indonesia.

Soepandi, Atik., Rosid Abdurahman, Iyus Rusliana, Tatang Suryana. 1986/1987.

Peralatan Hiburan dan Kesenian Tradisional di Jawa Barat. Departemen Pendidikan dan Kebudayaan, Direktorat Jenderal Kebudayaan, Direktorat Sejarah dan Nilai Tradisional, Proyek Inventarisasi dan Dokumentasi Kebudayaan Daerah.

Soepandi, Atik.1988.

Kamus Istilah Karawitan Sunda. Bandung: Pustaka Buana.

Suparlan, Y.B. 1988.

Kamus Kawi Indonesia.

Yogyakarta: Kanisius.

\section{Koran}

Haryadi Suadi,

"Dari "Sorban Palid" Nyi Mene Sampai "Es Lilin" Nyi Mursih". Harian Umum Pikiran Rakyat, Bandung 21 Oktober 1997.

Ieke Sartika Iriane.

"Persepsi Perempuan Sunda Berkeluarga”, Pikiran Rakyat, 4 Oktober 2001. 